\title{
FAIR VALUE OF NON-RIVALROUS FREE COMMUNAL GOOD: CONCEPT, ESTIMATION, AND APPLICATIONS
}

\author{
Justine Sophia Jaunzeme \\ Ventspils University of Applied Sciences, Latvia \\ justine.jaunzeme@venta.lv
}

\begin{abstract}
At the center of the current research lies the concept of assets' and liabilities' fair value, what is encountered in the International Public Sector Accounting Standards (IPSAS - in abbreviation). According to IPSAS, fair value is an alternative measurement base for property, plant and equipment and intangible assets. In the opinion of the author, the fair value concept in IPSAS is considered from too narrow point of view, since the concept of fair value is insufficiently associated with the asset's value concept used in the economic theory, financial theory, econometrics. This paper is the part of the research "Holistic approach to the fair value concept and estimation" provided by author. The purpose of this paper is to adopt the fair value concept defined in the IPSAS to the non-rivalrous free communal goods, which are financed by municipalities and government institutions from taxpayers' money, and to develop a practically applicable and algorithmized non-rivalrous free communal goods' fair value estimation method based on technological, economical. financial, and social surveys. Practically oriented research about non-rivalrous free communal goods' fair value estimation the author has never encountered in scientific literature available for the author - neither scientific papers in the field of accounting, nor in the field of economics. The theoretical concepts are illustrated with help of examples from empirical material which is borrowed from some published articles. The measurement of non-rivalrous free communal goods' fair value is an urgent issue because the Latvia's State Audit Office reported on inexpedient and economically unsubstantiated investments in non-rivalrous communal goods. The results of the current research have to be implemented in the state and municipal government authorities' practical decision making process to a range of investment projects for production of non-rivalrous free communal assets.
\end{abstract}

Keywords: fair value, non-rivalrous free communal good, tax payers, contingent valuation, monetary benefit flow, cost flow, duration, volatility.

\section{Introduction}

At the center of the current research lies the concept of assets' and liabilities' fair value, what is encountered in the International Public Sector Accounting Standards (IPSAS - in abbreviation). In the IPSAS Glossary of defined terms, fair value is defined as the amount for which an asset can be exchanged or liability settled between knowledgeable, willing parties in an arm's length transaction. According to IPSAS, fair value is an alternative measurement base for property, plant, equipment and intangible assets. Also instructions for application of the fair value measurement are provided in IPSAS [1]. IPSAS are applied by state and municipal institutions in preparation of their financial statements. The author argues that it is very important that state and municipal institutions apply fair value measurement for their assets, since the production of their assets is financed by taxpayers' money.

In the opinion of the author, the fair value concept in IPSAS is considered from too narrow point of view, since the concept of fair value is insufficiently associated with the asset's value concept used in the economic theory, financial theory, econometrics. It should be also noted that the methods of fair value estimation are poorly related to the algorithms of real estate value professional measurement. The general aim of the presented study paper is to continue the development of the holistic approach of fair value concept, estimation methods and applications, to which the paper "Holistic Approach to Fair Value Estimation" published in 2019 was devoted [2].

In the specific aspect, the purpose of this paper is to adopt the fair value concept defined in IPSAS to the non-rivalrous free communal goods (NRFC-goods - in abbreviation), which are financed by municipalities and government institutions from taxpayers' money, and to develop a practically applicable NRFC-goods' fair value estimation method based on alghoritmized technological, economical. financial, and social surveys.

The term "non-rivalrous" means that, if an individual consumes this benefit, the availability of this benefit to others will not be reduced. Communal goods are such assets, which are used by several people, for example, a bridge over the river, bike route, greenery in the center of the town, orderly beach, fireworks etc. An important example is the public libraries. Especially important will became 
the IT products elaborated for special groups of people. The goods for consumers are free, because their production is financed by municipalities and government institutions from taxpayers' money.

In order to achieve theoretical completeness and practical applications in NRFC-good's fair value estimation, it is useful to utilize some issues concerning valuation of public goods. The concept of the public good has a long history, the main ideas appear in the works of John Locke, David Hume, Adam Smith, and John Stuart Mill. Let us note that non-rivalroity of goods figuratively appears in some folktales. The Nobel Prize winner in economics Paul A. Samuelson is regarded as the first economist, who derived the modern discussion of public goods. In his work "The Pure Theory of Public Expenditure", published in 1954, he defined "the benefits of collective consumption" and implemented the terms "non-rivalrous" and "non-excludable" [3].

In our studies we are especially interested in the such specific feature of good as "non-rivalroity", when one person's consumption of that good does not reduce the amount available to other persons. The term "non-excludable" benefit means that no one can be excluded from the consumption of this benefit. Benefit, the amount of which does not decrease as it is consumed and from the consumption of which people cannot be delimited, is named as imperishable public good. In our studies of nonrivalrous free communal good, both features: "excludability" and "non-excludability" play a significant role. Because of essentially important sense of each attribute in the concept of the nonrivalrous free communal good, the abbreviation "NRFC-good" will be used.

Let us note that the non-rivalrous free communal good is not the same as public good.

The concept of public goods contains the attribute "non-excludable", which means that no one can be excluded from the consumption of this good and the good is available to all and cannot be withheld. So, the defining characteristic of a public good is impossibility of exclusion. At the same time, the NRFC-goods often are excludable. For instance, only the persons with the special reader card are allowed to attend the public library. The IT products could be available only for special groups of persons having a password. Likewise, the concepts of "NRFC-good" and "public good" have a different interpretation of the attribute "non-rivalrous". As for the concept of public goods, the feature "non-rivalrous" often is interpreted in the unlimited sense as imperishable public good, namely, as benefit, the amount of which does not decrease as it is consumed and from the consumption of which people cannot be delimited. For example, imperishable public benefit for all people of the world would be reduction of global warming. At the same time, for the concept of NRFC-good the feature "non-rivalrous" is interpreted more specifically, namely, the non-rivalroity of benefit refers to the definite groups of persons, for which the benefit is available according to the NRFC-good production and utilizing plan. The feature "imperishable public benefit" does not refer to the NRFC-goods at all.

Therefore, the valuation of public good and NRFC-good's fair value estimation are two different problems. However, the author tries to enrich the concept of fair value given by IPSAS and fair value estimation methods by adopting fruitful investigations of public goods performed in economics.

Articles by Baron J., Greene J. (1996) Brookshire, D. S., Thayer, M. A., Schulze, W. D., \& d'Arge, R. C. (1982), Clinch J.P., Murphy A. (2001), Boyle, K.J., Johnson F.R., McCollum D.W., Desvousges W.H., Dunford R.W., Hudson S.P. (1996), Schlapfer F. (2006), Coursey D.L., Schulze W.D. (1986) are devoted to estimation of the public goods value [4-9]. Brookshire, D. S., Thayer, M. A., Schulze, W. D., \& d'Arge, R. C. (1982) in their paper "Valuing public goods: a comparison of survey and hedonic approaches" compare hedonic and survey approaches to estimation of the public goods' value. Their empirical results provide evidence towards the validity of survey methods as a means of determining the value of public goods [6].

Articles by Clinch J.P., Murphy A. (2001), Boyle, K.J., Johnson F.R., McCollum D.W., Desvousges W.H., Dunford R.W., Hudson S.P. (1996), Schlapfer F. (2006), Coursey D.L., Schulze W.D. (1986) deal with contingent valuations of public goods [5; 7-9]. In their paper Clinch J.P., Murphy A. (2001) examined some outstanding issues in relation to the validity of using results from contingent valuation studies as a basis for policy-making. They demonstrate that there is a rationale for allowing for winners and losers in contingent valuation due to the fact that many externalities manifest themselves as costs to some and benefits to others [7]. In their researchBoyle, K.J., Johnson F.R., McCollum D.W., Desvousges W.H., Dunford R.W., Hudson S.P. (1996) concentrate on comparison of the validity of open-ended and dichotomous-choice questions in the surveys needed for estimation of 
the public goods value. They have found that the choice of questioning format may influence the actual amounts of estimates [5]. Schlapfer F. (2006) studied the effect of people's income on the willingness to pay for public goods and surprisingly found low income effect [9]. By the way, let us note that in our paper NRFC-good fair value estimation through contingent valuation the potential consumer manifests only his (her) pure willingness to pay without any regard to the ability to pay. The research of Coursey D.L., Schulze W.D. (1986) also is useful for NRFC-goods' fair value estimation method elaboration [8]. The authors studied the application of laboratory experiments to the contingent valuation of public goods. They argued that the technique of laboratory experimental methods is ideally suited for testing the relative performance of different contingent valuation surveys and for designing and evaluating new survey instruments of interest to policy makers. None of these articles, however, offers specific algorithm for public goods' fair value estimation.

As it was mentioned, the aim of the paper is to develop a practically applicable non-rivalrous free communal goods' fair value estimation method based on algorithmized technological, economical. financial, and social surveys. The author has never encountered in scientific literature available for the author - neither scientific papers in the field of financial and managerial accounting, nor in the field of economics, practically oriented research of such type. It is worth to stress that because of understandable reasons in scientific papers in economics the author has never met even the concept of "fair value" what characterizes a fundamental gap between IPSAS and economics. The total benefit cash flow, where the benefit is measured as consumers' total willingness to pay, is offered in this paperas a main tool for fair value estimation. The concept of total benefit cash flow, of course, corresponds to the contingent valuation of the public goods analyzed in the scientific literature of economics. Differently from public goods in this paper, the attention is paid to NRFC-goods with rather clearly identifiable group of consumers and time period of communal goods' usage. State and municipal authorities must ascertain the group of NRFC-goods consumers. For example, let us consider as characteristic a NRFC-good example public library, say, library in the small town Piltene in 2020. This library provides services, which are non-rivalrous only for certain group of registered persons, the services of library are excludable, since they are available only to persons with a reader card. Our target is to elaborate algorithmized methods allowing to find an answer to the question: "What is the fair value of this library in Piltene in 2020?" Or to the question: "What is the fair value of the bike route around the Busenieku lake in Ventspils in 2020?"

Practically oriented research of such type the author has never encountered in scientific literature available for the author - neither scientific papers in the field of financial and managerial accounting, nor in the field of economics. In spite of that, however, the studies of economic scientific papers, for example, the latest research of public goods are absolutely necessary in order to find deepest analogies between non-rivalrous free communal goods and public goods, especially applying the contingent valuation method. The total benefit cash flow, where the benefit is measured as consumers' total willingness to pay, in the current paper is recognized as a main tool for fair value estimation. The concept of total benefit cash flow corresponds to the contingent valuation of the public goods analyzed in the scientific literature of economics. Still, in this paper public goods are not considered, but attention is paid to non-rivalrous free communal goods with rather clearly identifiable set of consumers and time period of communal goods' usage.

The theoretical concepts are illustrated with help of examples from empirical material, which is borrowed from some published articles. As the examples have only illustrative character, the author did not change anything in these examples, for instance, the currency in LVL (Latvian lats) is used.

In the opinion of the author, the socioeconomic role of non-rivalrous free communal goods has not been explored enough and their possibilities to improve the welfare of society have not been used sufficiently. The author believes that one of the factors to increase the welfare of people is perfect understanding and utilizing the unique properties of NRFC-goods.

According to IPSAS, in the financial statements, public goods can be classified as property, plant and equipment and intangible assets, as well as expenses. An example of public goods recognized as property, plant and equipment are railways and garbage collectors; public goods classified as intangible assets are logos of municipalities; and public goods accounted for as expenses are the costs of fireworks. Property, plant and equipment and intangible assets are non-current (long-term assets) of state and municipal institutions, which serve several time periods, while expenses are taken to profit 
and loss account immediately. According to IPSAS, municipal and state institutions may voluntarily choose to measure their property, plant and equipment and intangible assets at fair value [1].

In order to be more precise and in order to apply an algorithmized state and municipal institution's investments efficiency control, the author offers to apply the term "non-rivalrous free communal good" (or NRFC-good, in abbreviation) instead of the term "public good".

The issue of NRFC-goods evaluation in Latvia gained particular significance after Latvia's State Audit Office report on inexpedient and economically unsubstantiated investments in swimming pools by municipalities of small villages [10]. Furthermore, in mass media, the discussion began about fair value of such particular NRFC-good as fireworks during festive days financed from taxpayers' money by municipalities [11]. According to the report of Latvia's State Audit Office "Municipalities borrow and build to no worries" - unsubstantiated projects create a substantial burden to municipal budgets in the future, the practice of many municipalities, by borrowing financing from the state budget for building of objects too large, inadequate to real situation and needs of the municipality demonstrate short-term vision and irresponsible attitude towards future expenses. Latvia's State Audit Office in 15 municipalities evaluated the economic support for such infrastructure projects, their planning and implementation. During the audit, sad perspective of the future was revealed. The costs of most of sports and recreation objects likely will not be recovered; and the maintenance costs every year will just increase [10].

Discussions also cover the utility of fireworks which are financed from municipal budget. For example, according to the survey by SKDS, $23.8 \%$ of Riga's inhabitants hold the opinion that during the 800th anniversary of Riga no fireworks should be made [11]. In the opinion of the author, in order to make economically based strategic decision, it would be useful to estimate the fair value of this specific NRFC-good.

The author is aware that research has not been completed and must be continued. In the opinion of the author, after detailed elaboration and discussion of the method and algorithmthe results of the current research have to be implemented in the state and municipal government authorities' practical decision making process to a range of investment projects for production of non-rivalrous free communal assets. Because of growing requirement of the transparencies of the taxpayers' money spending, a requirement should be implemented in IPSAS, which substantiates the state and municipal investment projects in production of non-rivalrous free communal goods with estimates of their fair value. Fair values of investments in NRFC-goods should be mandatory presented on the balance sheet in the financial statements of the state and municipal institutions and explained in the notes to the financial statements of state and municipal government authorities. That will allow to avoid subjective decisions and provide for a possibility to explain to inhabitants the advantage of each investment project. Note: all tables and figures in the current paper are created by the author using mathematical models and Microsoft Excel tools.

\section{Materials and methods}

\section{The central concepts}

The central concepts of the current research are: (a) the concept of assets' and liabilities' fair value according to IPSAS, (b) the concept of NRFC-good, which synthesis specific non-rivalrous feature and free communal consumption feature. The good for consumer is free because its production is financed by municipalities and government institutions from taxpayers' money. The presence of the attributes "non-excludable" or "excludable" depends of specific good in specific case.

The purpose of this paper is to adopt the fair value concept to the NRFC-good.

\section{The concept of non-rivalroity of good}

At first we are going to discuss the concept of non-rivalroity of good. This, generally speaking, unusual feature of good was noticed a long time ago, it appears already in some folk-tales. However, by all that the conditions of production of non-rivalrous goods remain a serious social problem, which concentrates in short, but fundamental dilemma "mine or our?" The production of non-rivalrous goods does not significantly differ from production of private goods. The purchase of non-rivalrous goods, 
however, significantly differs from purchase of private goods, because fundamental problems arise concerning the question "Who will pay for this good?"

We offer a simple microeconomic model to detect the deepest social contradictions in the market of non-rivalrous goods.

Let us assume three persons' demand functions for a certain good are

$$
q_{1}=D_{1}(p), q_{2}=D_{2}(p), q_{3}=D_{3}(p),
$$

where $p$-the price of a product;

$q_{1}, q_{2}, q_{3}$ - the quantities which respective persons are willing and able to buy, if the price of the product is $p$;

$D_{1}, D_{2}, D_{3}$ - the demand functions of respective individuals.

The market demand in the case of private good's forms as the sum of the particular demands of individuals:

$$
q=D_{1}(p)+D_{2}(p)+D_{3}(p)
$$

where $p$-the price of the product;

$q$ - the quantity which persons summary are willing and able to buy, if the price of the product is $p$.

The summary purchase and consumption model of non-rivalrous good has been researched less.

\subsection{Simplified model of purchase}

In the Managerial Economics and Business Strategy courses, simplified situation, when all individuals have one and the same demand function, usually is considered:

$$
q_{1}=D(p), q_{2}=D(p), q_{3}=D(p) .
$$

For example, in the excellent book of Michael R. Baye (1999) the model of public goods (streetlight) purchasing is offered, when all three individuals $\mathrm{A}, \mathrm{B}, \mathrm{C}$ have identical inverse demand function $p=D^{-1}(q)$ for non-rivalrous communal good. In such a case the problem has a simple solution [12].

Let us assume that the given market price of non-rivalrous communal good is $p_{0}$. Three persons $A$, $B, C$ agree to contribute money for purchasing that non-rivalrous good. What amount of good these persons will buy by contributing their payments? How much each of the individuals will have to pay?

The amount of the common purchase $q_{0}$ is determined as solution of the equation (2) with respect to the quantity $q$ :

$$
D^{-1}(q)+D^{-1}(q)+D^{-1}(q)=p_{0},
$$

where $p_{0}-$ the given market price of the product;

$D^{-1}(q)$ is the inverse demand function of each individual.

Respectively, each individual pays one third of the market price $p_{0}$ for the common amount of purchase $q_{0}$.

\subsection{General model of purchase}

The author offers the following general model of purchase of non-rivalrous good and its interpretation.

Let the given market price of non-rivalrous good be $\mathrm{p}_{0}$ and three individuals agree to contribute their payments for purchase and consumption of this good. What amount of good these persons will buy by contributing their payments? How much each of the individuals will have to pay?

The total amount of the common purchase $q_{0}$ is determinedas solution of the equation (3) with respect to the quantity $q$ :

$$
D_{1}^{-1}(q)+D_{2}^{-1}(q)+D_{3}^{-1}(q)=p_{0}
$$

where $p_{0}$-the market price of the product;

$D_{1}^{-1}(q), D_{2}^{-1}(q), D_{3}^{-1}(q)$ - the respective inverse demand functions of three individuals.

For common purchase of the quantity $q_{0}$ three individuals pay 


$$
D_{1}^{-1}\left(q_{0}\right) \cdot q_{0}, D_{2}^{-1}\left(q_{0}\right) \cdot q_{0}, D_{3}^{-1}\left(q_{0}\right) \cdot q_{0},
$$

respectively. Apparently, the payments of three individuals for $q_{0}$ form a market value of $q_{0}$ :

$$
D_{1}^{-1}\left(q_{0}\right) \cdot q_{0}+D_{2}^{-1}\left(q_{0}\right) \cdot q_{0}+D_{3}^{-1}\left(q_{0}\right) \cdot q_{0}=p_{0} \cdot q_{0} \text {. }
$$

Let us stress that the payments of individuals for a good $q_{0}$, generally speaking, differ, but the possibilities to consume the non-rivalrous good are the same for everybody. A significant socioeconomic problem is revealed, which relates to private interest of economic agents and social necessity. It is most likely that three individuals with different demand functions will not be able to agree on common purchase and consumption of non-rivalrous good.

In the analysis of purchase of non-rivalrous non-excludable goods, a "free riders" problem plays a significant role: "Let others pay, I still will be able to consume the good". The free riders' problem is closely related to the problem of greedy selfish use of freely accessible goods, which has been formulated in the paper "The Tragedy of the Commons" by Garrett James Hardin (1968) [13].

It is the reason why the production of non-rivalrous communal goods is financed by taxpayers' money and involves discipline and centralized planning. Here fundamental, ancient and dialectical controversy between liberal economics, which precluded government intervention on the free market, and the necessity of government intervention in order to produce NRFC-goods, is revealed. On the one hand, by recognizing the high efficiency of liberal economics, we accede to laissez-faire appeal by Adam Smith. On the other hand, high utility of NRFC-goods calls for expanded government intervention in the market. The economics of NRFC-goods leads to the theory of economics' socialization, which has been repeatedly discussed during the last half of the century.

\section{Structure for research of the fair value of the NRFC-good}

The author offers the following structure for research of the fair value of the NRFC-good. Let us stress that at first we consider absolutely theoretical concepts. The question of the practical application of such theoretical constructions will be considered later.

\subsection{The technical project of planned non-rivalrous free communal good}

NRFC-good must be clearly defined and displayed with help of the technological project as an investment project. For example, technical specification of a designed swimming pool, planned bicycle route or a public library.

\subsection{Potential consumers as flow of groups of people}

The potential planned NRFC-good consumers defined with time periods (for example, month, quarter or a year), groups' of people flow $N=\left(N_{1}, N_{2}, \ldots, N_{m}\right)$ must be determined. Here $N$ is flow by groups of people, $\mathrm{m}$ is the number of periods, during which NRFC-good can be used, and $N_{k}$ are the groups of people, which during the k-th period can potentially use the good. In simpler cases, characteristics of sets $N_{k}$ can be only the number of people. However, sometimes it is purposeful to ascertain the structure of persons' assemblage $N_{k}$, for example, children, youth, retired persons etc. In many cases the groups of inhabitants $N_{k}$ can be perfectly described, even with family names.

\subsection{The cash flow of total willingness to pay}

Total benefits' flow $T B=($ benefit_1, benefit_2,$\ldots$, benefit_m $)$. Total benefits are measured by people's periodic total willingness to pay for consuming of NRFC-good according to the predicted flowof groups of consumers $N=\left(N_{1}, N_{2}, \ldots, N_{m}\right)$. Let us stress that differently from many methods of public good's valuation we are interested only in the pure willingness to pay,but do not consider the ability to pay. In order to forecast the total benefit flow, complicated economical, sociological and psychological research is necessary. Inhabitants must clearly determinein monetary termsthe potential surplus gained from the planned NRFC-good.

\section{Non-rivalrous free communal good fair value definition.}

The economists know that the comparison of alternative investments is still being actively researched. The author agrees with James C. Van Horne, John M. Vachowiz Jr, whoin their book "Fundamentals of Financial Management" published in 2003 write: "The criterion for acceptance of 
long-term investments is probably the hardest and most controversial issue in the field of financial management [14]". Let us note that the comparison of alternative investments in the production of NRFC-goods is significantly more complex and sensitive than the comparison of purposefulness of business investments.

In order to compare different NRFC-goods production investment projects, the crucially important role has the knowledgeabout the fair value of NRFC-goods. The author will base the fair value of NRFC-goods on its fundamental value and offers the method of fundamental value estimation basing on the formula provided by Irving Fisher (1906). Irving Fisher recognizes the value of an asset as the present value of the cash flows, which are expected to be generated by an asset. According to Irving Fisher, "value today always equals future cash flow discounted at the opportunity cost of capital [15]". Robert C. Merton and Zvi Bodie (2004) particularize the formulation by Irving Fisher and use the term "fundamental value." In their book, the fundamental value of an asset is defined as a price, which well informed investors would pay for an asset in the market of perfect competition [16]. The asset's fundamental value and the market price might not coincide, therefore, financial analysts try to identify undervalued and overvalued assets.

The thesis of the author discussed in the previous papers is that under ideal conditions, in the market of perfect competition the asset's fair value equals to the asset's fundamental value. Just as market loses the characteristics of perfect competition, for example, as in the case of capital concentration firms assume market power, the determination of the asset's fair value becomes more complicated.In this paper, the author offers to define the fair value of NRFC-good as the fundamental value of the total benefits' flow. People must be surveyed in order to estimate their pure willingness to pay, which determines the total benefits' flow. The results of the survey will depend only on people's preferences and honesty of answers.

Thus, in the definition of NRFC-good's fair value, in-depth development and synthesis of the ideas of Paul Samuelson (1954), Irving Fisher (1906) and Robert C. Merton (2004) within the framework of information economics has been carried out.

\section{The calculated cost flow of initial investments and periodic maintenance costs}

By means of further detailedeconomic analysis of investments, the amount of initial investments $S$ and periodic maintenance costs cost_k have to beestimated; the flow of periodic maintenance costs $M C=\left(\right.$ cost 1, cost $\_2, \ldots$, cost_m $)$, where $m$ is the number of periods during which NRFC-good can be used, must be prepared according to current prices. This is a typical task of determining maintenance costs for periods when the good will be used (months, quarters, years etc....). The determination of maintenance costs' cash flows requires diligent economic analysis and forecasting.

\section{The fundamental value of non-rivalrous free communal good and the fundamental value of the corresponding maintenance cost flow}

Estimation of non-rivalrous free communal goods' initial investments and estimation of the fundamental value of further maintenance costs'flow MC is needed for support of investment projects. Estimation of the amount of initial investment and maintenance costs' cash flow fundamental value is regarded as an economic and technological issue well known in making of business strategic decisions. We can recommend the book of Zvi Bodie and Robert C. Merton "Finance" published in 2004 [16].

Society's welfare is a principally different concept than the maintenance costs of an asset, therefore, in the calculations of the total benefit's flow fundamental value different discount rate than the one used for the total maintenance costs' fundamental value could be chosen.

By taking into account that the usage of NRFC-goods can take several decades, estimates of total benefit flow duration and volatility, as well as total maintenance cost flow duration and volatility are significant.

If the maintenance costs' cash flow and total benefits' cash flow are constructed, the fundamental values of these cash flows as functions of the interest rate i according to the method of Irving Fisher [17] must be calculated.In the formulas (5)-(10) the following notations are used:

- $\quad P V(M C, i)$ - fundamental value of maintenance costs' cash flow;

- $\quad P V(T B, i)$ - fundamental value of total benefits' cash flow; 
- duration $(M C, i)$ - duration of maintenance costs;

- $\operatorname{volatility}(M C, i)$ - volatility of maintenance costs;

- duration $(T B, i)$ - duration of total benefits;

- $\operatorname{volatility~}(T B, i)$ - volatility of total benefits;

- $m$ - number of time periods when costs are incurred;

- cost_m-cost during the time period $\mathrm{m}$;

- benefit_m - total benefit during the time period $\mathrm{m}$;

- $i$-interest rate;

- $v$-discount factor.

The fundamental value of the maintenance costs' cash flow $P V(M C, i)$ :

$$
P V(M C, i)=v \cdot \operatorname{cost} \_1+v^{2} \cdot \cos t \_2+\ldots+v^{m} \cdot \operatorname{cost} \_m .
$$

The fundamental value of the total benefits' cash flow $P V(T B, i)$ :

$$
P V(T B, i)=v \text { tifene } b \cdot 1+v^{2} \text { tifene } b \cdot 2+\ldots+v^{m} \text { tifene } b \cdot m \text {. }
$$

Since useful life of NRFC-good can last decades, significance will be attached to estimates of total benefits' flow volatility and duration, as well as estimates of total maintenance costs' volatility and duration. For example, bridges, roads, beaches, security services can have long exploitation terms, the duration of cash flows may be rather long, for example, 10 years. That is why the estimated fair value can have high volatility, that is, high sensitivity to the interest rate changes.

Duration and volatility of the maintenance costs are determined by equations (7), (8) accordingly:

$$
\begin{aligned}
\operatorname{duration}(M C, i)= & \left(1 \cdot v \cdot \cos t_{-} 1+2 v^{2} \cdot \cos _{-} 2+\ldots+m \cdot v^{m} \cdot \cos t_{-} m\right) / P V(M C, i), \\
& \text { volatility }(M C, i)=- \text { duration }(M C, i) \cdot v .
\end{aligned}
$$

Duration and volatility of total benefits are determined by equations (9), (10) accordingly:

$$
\begin{gathered}
\text { duration }(T B, i)=\left(1 \cdot v \text { tifeneb }{ }_{-} 1+2 \cdot v^{2} \text { tifene } b_{-} 2+\ldots+m \cdot v^{m} \text { tifene } b \cdot m\right) / P V(T B, i) \\
\text { volatility }(T B, i)=-\operatorname{duration}(T B, i) \cdot v .
\end{gathered}
$$

\section{Fair value of non-rivalrous free communal good as the function of the interest rate}

The fundamental value of maintenance costs as the function of the interest rate. The author would like the discuss an important question: How to choose adequate interest rate to calculate the fundamental value of total benefits' cash flow $P V(T B, i)$ and the fundamental value of maintenance costs' cash flow $P V(M C, i)$ ?

Assuming that financial market is the market of perfect competition, the interest rate is time value of money. Irving Fisher (1906) and Robert C Merton (2004) use the concept of opportunity cost of capital or weighted average cost of capital WACC [15; 16]. Cost of capital means risk adjusted interest rate, which is necessary for the investment project to be acceptable, by taking into account alternative investment opportunities under given market conditions. What concerns the business investment projects, the issue of the interest rate choice is widespread. Determination of cost of capital for the purpose of estimation offair value of NRFC- good is not discussed enough in literature. People's surplus is a principally different concept from maintenance costs, therefore, for the purpose of the total benefits' fundamental value calculation the author will use different discount rate than for calculation of the total maintenance costs' fundamental value. For NRFC-goodfair value estimation the author recommends to choose lower interest rate, because the welfare of people cannot be measured in terms of profit.

The author shall note that meticulous discussions about the interest rate choice as investment projects are evaluated, generally speaking, are futile. In the opinion of the author, when analyzing and selecting investment projects not specific net present values or other numeric indicators obtained by discounting (for example, profitability index, duration etc.), should be used, but the functions of interest rate and graphic charts of respective functions for a wide range of interest rates. Information technologies allow for easy creation of such graphic charts. 
As real situations areanalyzed, the author advises not to confine oneself to calculations which include certain interest rates, but to represent the relevant relationships graphically by obtaining the dependence of indicators on varied rates of interest.

Therefore, the author offers to define the fair value of non-rivalrous free communal good not as an numeric indicator, but as the function $P V(T B, i)$.

\section{Example}

With a simplified example the author will explain the financial meaning of functions $P V(T B, i)$, $P V(M C, i)$ and $P V(T C, i)=$ initial investment $+P V(M C, i)$.

It will be assumed that Samsu municipality wishes to bestow fruits worth EUR 1000 each year for children. Samsu municipality operates in the financial market of perfect competition, where interest rate represents the time value of money. It will be assumed that the interest rate is $8 \%$ per year.

The municipality has to choose between two alternatives.

According to the first alternative, entrepreneur Braun agrees to supply fruits, if municipality now grants him EUR 4013 as a loan. Then amounts of money worth EUR 1000 would serve as loan repayment annuity for 6 years.

According to the second alternative, entrepreneur Green commits to plant a garden, by investing EUR 2000 now. Such a garden would allow to supply Samsu children with fruit worth EUR 1000 each year for a 5-year period. Tending of the garden, however, requires spending of EUR 450 each year. Thus, the costs consist of the initial investment EUR 2000 and cash flows spent on tending the garden $(450,450,450,450,450)$.

Which alternative is more remunerative to Samsu municipality? Analysis follows. If the interest rate is $8 \%$, the fundamental value of the benefits cash flow equals EUR 3993. Thus, if the time value of money is measured by $8 \%$ yearly interest rate, then the fair value of the charity event (the supply of Samsu children with fruits for a 5-year period) equals EUR 3993. Let us consider the amount EUR 3993 as the fair value of free communal good with respect to $8 \%$ interest rate.

In the case of entrepreneur Braun, internal rate of return of cash flow $(-4013,1000,1000,1000$, $1000,1000)$ is $4 \%$. It means that, if the municipality chooses this alternative, it has invested EUR 4013 at a $4 \%$ annual interest rate.

In the case of entrepreneur Green, fundamental value of costs of tending the garden with respect to $8 \%$ interest rate equals 1805 euros. Adding up the initial costs of planting the garden EUR 2000, the author obtains EUR 3805. Thus, economically more advantageous is the alternative offered by entrepreneur Green, since 3993-3805 = 188 .

In the example, Figure 1 presents that given the interest rate $12 \%$ both alternative fundamental values of cash flows coincide. If the interest rate would increase to $18 \%$, then the alternative of entrepreneur Braun would be more economically advantageous.

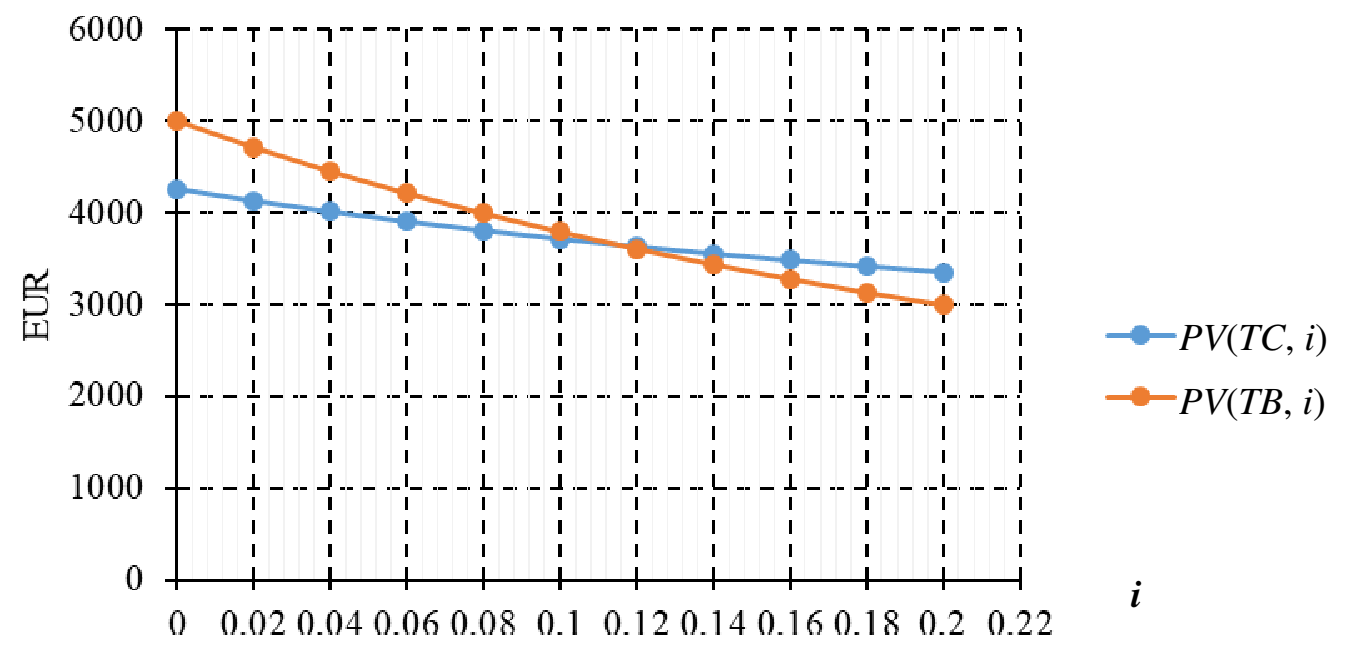

Fig. 1. Graphs of fundamental values $P V(T C, i), P V(T B, i)$ 


\section{Results and discussion}

In order to demonstrate practical application of non-rivalrous free communal goods fair value estimation, the author will apply the two empirical examples of Ventspils city municipal projects (Ventspils pilsētas pašvaldības projekti) presented in the paper by Jaunzems A., Bolezina I., Norkuss N. (2014) [17]. The examples have only illustrative character, therefore the author did not change anything in these examples, for instance, the currency in LVL (Latvian lats) is used.

\section{Project "Development of cycling tourism in Ventspils city"}

Within the project of cycling tourism development, 10.17 kilometers long cycle routes were built in Ventspils, connecting the international ferry terminal with popular objects of tourism in the city Old Town, Port Promenade, Southern Pier, Seaside and Adventure Parks, thus improving the cycling infrastructure and offering a new product of tourism to guests of the city. The building of bicycle routes provides for safe movement of cyclists and improves the access to tourism objects. Orderly infrastructure of cycling not only furthers the bicycle tourism, but also creates value-added to the offers of tourism and environment where it is located. The offered bicycle routes not only will allow for the city to be integrated in the Euro Velo net, but also will further the mobility of Ventspils inhabitants. In order for local and foreign tourists to navigate in the city, the brochure "Bicycle routes in the Ventspils city has been published as part of the project; the bicycle routes already built as well as the planned ones are presented in the brochure. The brochure is publicly available also in section of the visitventspils.com website "For cyclists".

Total cost of the project is LVL 863379; ERAF financing is LVL 699345; financing from the state budget is LVL 37029; financing from Ventspils city municipal budget is LVL 127005. The useful life of bicycle routes is estimated to be 10 years. According to estimates of the author, the number of potential users of the bicycle routes is approximately 50000 people annually. As a result of surveys, the average ability to pay for the bicycle routes is EUR 20 per year. Total maintenance costs of the project are LVL 50000 annually.

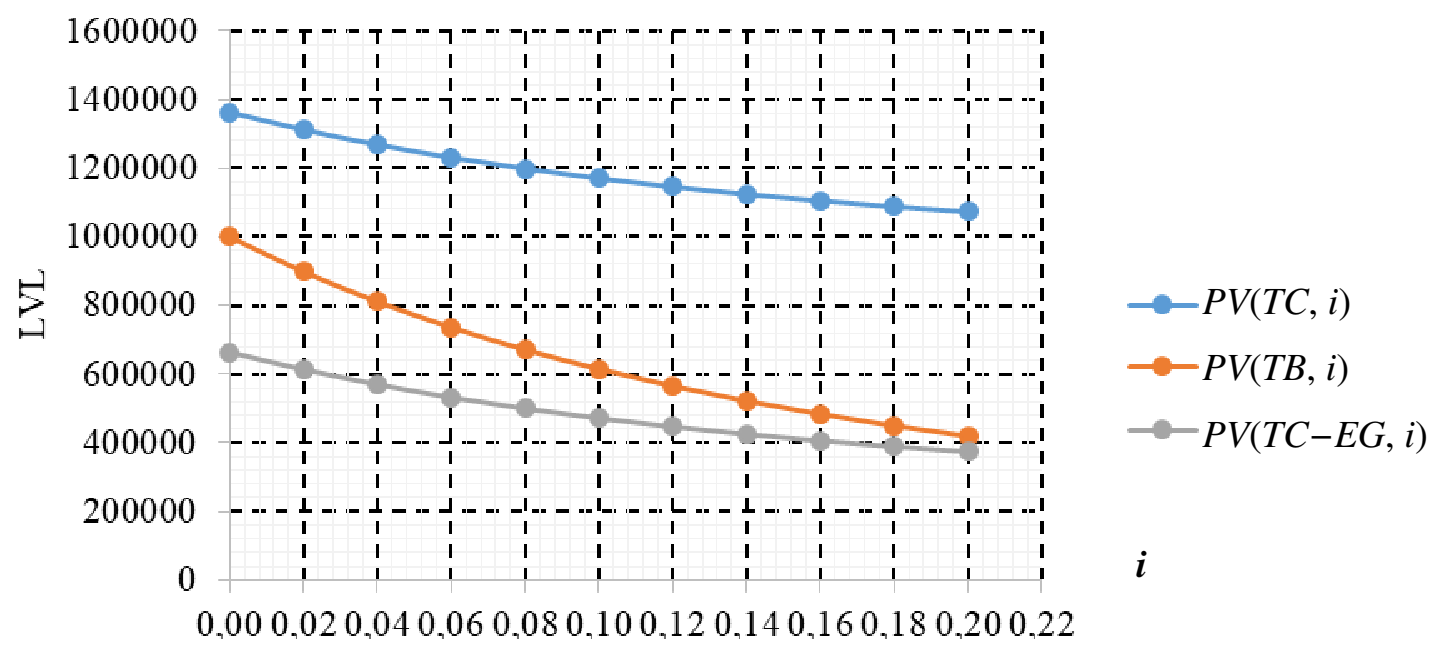

Fig. 2. Graphs of fundamental values $P V(T C, i), P V(T B, i), P V(T C-E G, i)$ for investment project "Eurovelo in the Ventspils city"

As the calculations show, without the European grant the fundamental value of total costs of development of the cycling routes exceeds the fundamental value of total benefits for a wide range of interest rates i. However, if the European grant is received, the fundamental value of total benefits of the non-private good plus the European grant for given project exceed the fundamental value of total costs. Certainly, municipality takes this into account.

Table 1 demonstrates that volatility of the maintenance costs $(M C, i)$ for the wide range of interest rates remains in the interval $[-5 ;-4]$, thus indicating moderate fluctuations of the fundamental value, as the interest rate fluctuates. For example, if the interest rate falls from $10 \%$ to $8 \%$, the fundamental value of the maintenance costs increases from LVL 307228 to LVL 335504, that is by $9.2 \%$. 
Calculated information for decision making considering the project

"Eurovelo in the Ventspils city"

\begin{tabular}{|c|c|c|c|c|c|c|c|}
\hline $\boldsymbol{i}$ & $\boldsymbol{P V}(\boldsymbol{T C}, \boldsymbol{i})$ & duration $(\boldsymbol{M C}, \boldsymbol{i})$ & volatility $(\boldsymbol{M C}, \boldsymbol{i})$ & $\boldsymbol{P V}(\boldsymbol{T B}, \boldsymbol{i})$ & $\boldsymbol{P V}(\boldsymbol{T C}, \boldsymbol{i})-\boldsymbol{E G}$ & $\boldsymbol{P V}(\boldsymbol{T B}, \boldsymbol{i})-\boldsymbol{P V}(\boldsymbol{T C}, \boldsymbol{i})$ & $\begin{array}{c}\boldsymbol{P V}(\boldsymbol{T B}, \boldsymbol{i})- \\
\boldsymbol{P V}(\boldsymbol{T C}, \boldsymbol{i})+\boldsymbol{E} \boldsymbol{~}\end{array}$ \\
\hline 0.00 & 1363379 & 5.50 & -5.5 & 1000000 & 664034 & -363379 & 335966 \\
\hline 0.02 & 1312508 & 5.34 & -5.2 & 898259 & 613163 & -414250 & 285095 \\
\hline 0.04 & 1268924 & 5.18 & -5.0 & 811090 & 569579 & -457834 & 241511 \\
\hline 0.06 & 1231383 & 5.02 & -4.7 & 736009 & 532038 & -495375 & 203970 \\
\hline 0.08 & 1198883 & 4.87 & -4.5 & 671008 & 499538 & -527875 & 171470 \\
\hline 0.10 & 1170607 & 4.73 & -4.3 & 614457 & 471262 & -556151 & 143194 \\
\hline 0.12 & 1145890 & 4.58 & -4.1 & 565022 & 446545 & -580868 & 118477 \\
\hline 0.14 & 1124185 & 4.45 & -3.9 & 521612 & 424840 & -602573 & 96772 \\
\hline 0.16 & 1105040 & 4.32 & -3.7 & 483323 & 405695 & -621718 & 77627 \\
\hline 0.18 & 1088083 & 4.19 & -3.6 & 449409 & 388738 & -638675 & 60670 \\
\hline 0.20 & 1073003 & 4.07 & -3.4 & 419247 & 373658 & -653755 & 45590 \\
\hline
\end{tabular}

Code and Description:

$i$-interest rate as time value of money in the financial market of perfect competition;

$P V(T C, i)$ - fundamental value of total costs with respect to the interest rate $i$;

duration $(M C, i)$ - duration of the maintenance costs (MC) flow with respect to the interest rate $i$; $\operatorname{volatility}(M C, i))$ - volatility of the maintenance costs (MC) flow with respect to the interest rate $i$; $P V(T B, i)$ - fundamental value of total benefit with respect to the interest rate $i$;

$E G-$ the European grant for given project.

\section{Project "Building of a new nursery in Kuldiga street 134 in Ventspils"}

In 2010, in Ventspils on Kuldiga street 134 a new nursery "Bitīte" was opened. A new building of the nursery covering $2277.4 \mathrm{~m}^{2}$ was built. In the new nursery, premises for groups of children from 3 to 7 years old were arranged in two levels. On the first floor premises for lessons and play for children, as well for each group individually a dressing room and bathroom were arranged, and on the second floor - bedrooms. For the youngest children, the bedroom is situated next to the room for lessons easily overseen by teachers and nurses. Children from 3 to 7 years old can have meals in a sunny and equipped dining room, built specially for this purpose. For each group of children, a separate entry from the territory of the nursery is provided, where children will have access to varied colorful, interesting and developing playgrounds and play equipment. In the dressing room of each group a wardrobe for drying clothing is installed, which will provide for dry footwear and clothing under any weather conditions. 38 new working positions are created. Employment is furthered for at least 154 inhabitants, the children of which can attend the nursery. Access to environment is improved for families with children in Ventspils city nursery and its territory.

Total cost of the project - LVL 1591312; financing by ERAF is LVL 1194767; financing from the state budget is LVL 63252; financing from Ventspils city municipality is LVL 333293. Useful life of nursery is 50 years. The number of consumers is 154 children annually. Average ability to pay is LVL 300 per year (payment by parents). Since the project is not expected to have other realization times or significant investments, then the total maintenance costs, which are LVL 200107 per year, are also regarded as investments. Maintenance costs are significant and therefore are involved in the calculations.

Costs of the project both the initial investment and maintenance costs are so high that consumers with their ability to pay do not cover them. Here the author can speak about the socioeconomic role of the municipality - subsidizing of non-private investments. Under liberal market conditions, such a project would not be realized, but due to intervention of the municipality and due to deliberate redistribution of capital, this project exists.

As the calculations show, even with the European grant the fundamental value of total cost of the project exceeds the fundamental value of total benefits for the wide range of the interest rate $i$. This mainly can be explained by the fact that non-private good can be used by small amount of people (154 
children). If the municipality still decides to realize this project, then apparently it bases on other considerations.

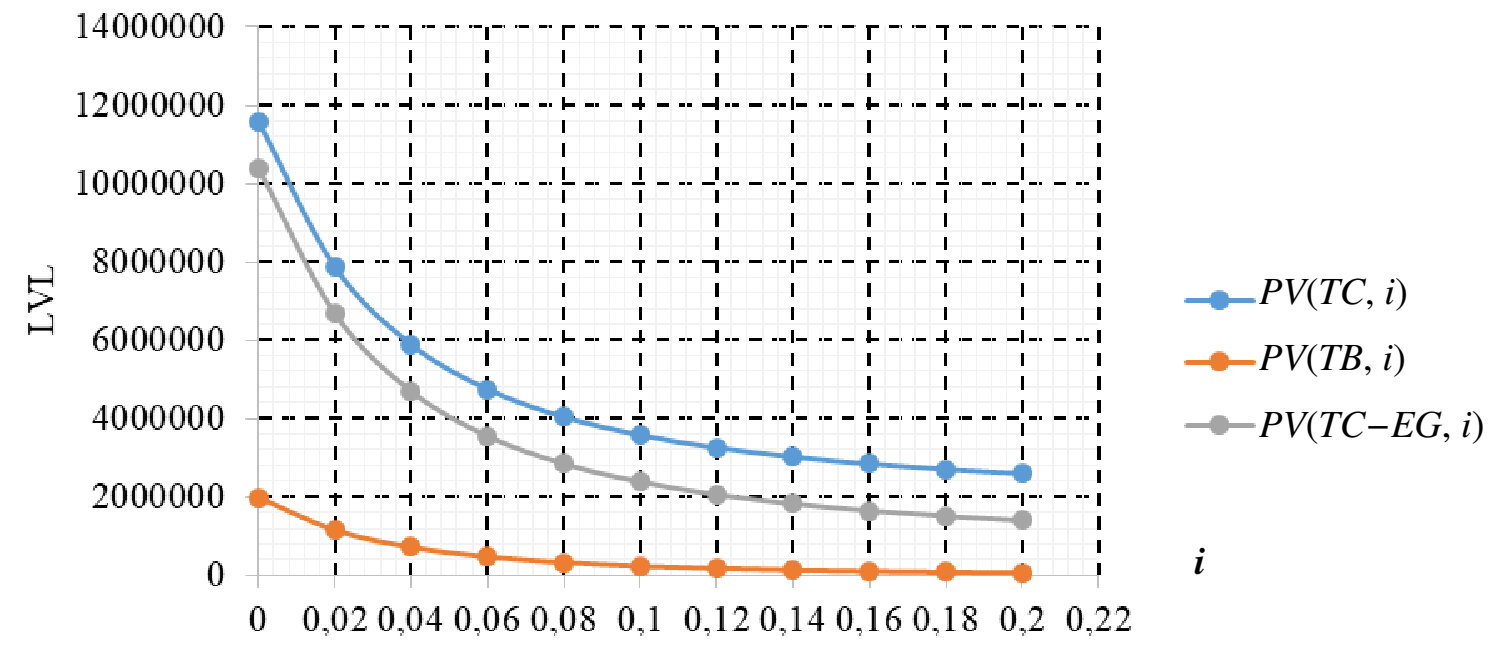

Fig. 3. Graphs of fundamental values $P V(T C, i), P V(T B, i), P V(T C-E G, i)$ for investment project "Bērnu dārzs "Bitīte"

Table 2

Calculated information for decision making considering the project "Bērnudārzs "Bitīte"

\begin{tabular}{|c|c|c|c|c|c|c|c|}
\hline$i$ & $P V(T C, i)$ & duration $(M C, i)$ & volatility $(M C, i)$ & $P V(T B, i)$ & $P V(T C, i)-E G$ & $P V(T B, i)-P V(T C, i)$ & $\begin{array}{r}P V(T B, i)- \\
P V(T C, i)+E G\end{array}$ \\
\hline 0.00 & 11592162 & 25.50 & -25.5 & 2310000 & 10397395 & -9605562 & -8410795 \\
\hline 0.02 & 7876567 & 21.44 & -21.0 & 1451771 & 6681800 & -6723803 & -5529036 \\
\hline 0.04 & 5888114 & 17.81 & -17.1 & 992477 & 4693347 & -5172932 & -3978165 \\
\hline 0.06 & 4743952 & 14.80 & -14.0 & 728198 & 3549185 & -4273660 & -3078893 \\
\hline 0.08 & 4038217 & 12.41 & -11.5 & 565187 & 2843450 & -3713564 & -2518797 \\
\hline 0.10 & 3574443 & 10.57 & -9.6 & 458064 & 2379676 & -3341300 & -2146533 \\
\hline 0.12 & 3252353 & 9.16 & -8.2 & 383668 & 2057586 & -3079531 & -1884764 \\
\hline 0.14 & 3017965 & 8.07 & -7.1 & 329529 & 1823198 & -2886556 & -1691789 \\
\hline 0.16 & 2840670 & 7.22 & -6.2 & 288577 & 1645903 & -2738675 & -1543908 \\
\hline 0.18 & 2702235 & 6.54 & -5.5 & 256601 & 1507468 & -2621726 & -1426959 \\
\hline 0.20 & 2591287 & 5.99 & -5.0 & 230975 & 1396520 & -2526845 & -1332078 \\
\hline
\end{tabular}

Code and Description the same as to Table 2.

Table 2 demonstrates that volatility of the maintenance costs $(M C, i)$ stays in the interval $[-8 ;-15]$ for a wide range of interest rates, which indicates significant fluctuations of the maintenance costs, as interest rates change, and increase the risk of investments. For example, if the interest rate i falls from $10 \%$ to $8 \%$, the fundamental value of the maintenance costs increases from LVL 1983131 to LVL 2446905 , that is, by $23.4 \%$.

\section{Conclusions}

1. Non-rivalrous communal good is characterized by concept "non-rivalrous" in a limited sense, which means, if an individual consumes this benefit, the availability of this benefit to others will not be reduced, but only for a defined group of people. The concept "non-excludable", which means that no one can be excluded from the consumption of given good, is not a typical attribute of non-rivalrous communal good. As a rule, the consumption of the NRFC-good is excludable, e. g. the consumption is available only for definite groups of persons.

2. The production of non-rivalrous communal goods by combining the payments of individuals often is not possible due to differing preferences of individuals. Therefore, the theory of economics 
recommends to produce non-rivalrous communal goods mainly by use of taxpayers' money. As the result, these goods seem for consumers as free.

3. In order to make substantiated decisions for the governments, the necessity arises to evaluate the purposefulness of producing every certain NRFC-goodcompared to purposefulness of producing another NRFC-good. The author offers the following information instruments:

a. technical project of the planned NRFC-good;

b. potential planned NRFC-good consumers defined with a time period's (for example, month, quarter or a year) inhabitantgroups flow $N=\left(N_{1}, N_{2}, \ldots, N_{m}\right)$;

c. cash flow of total willingness to pay TB $=$ (benefit_1, benefit_2, 2 , nefitbe_m), associated with the technical project and design of the planned good and according to the forecasted groups of consumers flow $N=\left(N_{1}, N_{2}, \ldots, N_{m}\right)$;

d. initial investments $\mathrm{S}$ and cost flow of periodic maintenance costs $M C=\left(\cos _{-} 1\right.$, cost_2, ..., cost_m).

4. The author offers to define the fair value of non-rivalrous free communal good not as a numeric indicator but as the function $P V(T B, i)$.

5. The decision about investments in the current NRFC-good must be done by means of analysis of the following functions: $P V(T B, i)$ - fundamental value of total benefits' cash flow; duration $(T B, i)$ - duration of total benefits; $\operatorname{volatility}(T B, i)$ - volatility of total benefits; $P V(M C, i)$ - fundamental value of maintenance costs' cash flow; duration $(M C, i)$ - duration of maintenance costs; volatility $(M C, i)$ - volatility of maintenance costs.

6. The measurement of NRFC-goods' fair value is an urgent issue in Latvia in order to avoid the inexpedient and economically unsubstantiated investments in non-rivalrous communal goods. The fair values of investments in non-rivalrous free communal goods should be compulsory reported in the financial statements of the state and municipal institutions. That will allow to avoid subjective decisions and provide for a possibility to explain to inhabitants the advantage of each investment project.

7. In order to be more precise and in order to apply algorithmized investment efficiency control at state and municipal institutions, the author offers to apply the term "non-rivalrous free communal good" instead of the term "public good".

\section{References}

[1] Handbook of International Public Sector Accounting Pronouncements. I, II, III Edition. - New York: International Public Sector Accounting Standards Board, 2019. 2825 p.

[2] Jaunzeme J. Holistic Approach to Fair Value Estimation. 17th International Scientific Conference "Engineering for Rural Development" - Jelgava: LLU, 2019. pp. 1786-1794. [online] [14.03.2020.] Available at: http://www.tf.llu.lv/conference/proceedings2019/Papers/N062.pdf

[3] Samuelson P. A. The Pure Theory of Public Expenditure -Review of Economics and Statistics 36, 1954.

[4] Baron J., Greene J. Determinants of Insensitivity to Quantity in Valuation of Public Goods: Contribution, Warm Glow, Budget Constraints, Availability, and Prominence. - Journal of Experimental Psychology, 1996, Vol. 2, No. 2, pp. 107-125.

[5] Boyle, K.J., Johnson F.R., McCollum D.W., Desvousges W.H., Dunford R.W., Hudson S.P. Valuing Public Goods: Discrete versus Continuous Contingent-Valuation Responses. - Land Economics, Vol. 72, No. 3 (Aug., 1996), pp. 381-396.

[6] Brookshire S.D., Thayer M.A., Schulze W.D., d'Arge R.C. Valuing Public Goods: A Comparison of Survey and Hedonic Approaches. - The American Economic Review, Vol. 72, No. 1 (Mar., 1982), pp. 165-177.

[7] Clinch J.P., Murphy A. Modelling winners and losers in contingent valuation of public goods: appropriate welfare measures and econometric analysis. - The Economic Journal, 111 (April, 2001), pp. 420-443.

[8] Coursey D.L., Schulze W.D. The Application of Laboratory Experimental Economics to the Contingent Valuation of Public Goods. - Public Choice, Vol. 49, No. 1 (1986), pp. 47-68.

[9] Schlapfer F. Survey protocol and income effects in the contingent valuation of public goods: A meta-analysis. - Ecological Economics 57 (2006), pp. 415-429. 
[10] Valsts kontrole: pašvaldības aizṇemas un būvē uz nebēdu (State Audit Office: Municipalities borrow and build to no worries) [online] [14.03.2020.] - Available at https://lvportals.lv/norises/308356-valsts-kontrole-pasvaldibas-aiznemas-un-buve-uz-nebedu2019.

[11]Kādu salūtu vajag Rīgas 800. jubilejāe (What fireworks are necessary for Riga's 800th anniversary?) [online] \{14.03.2020.] - Available at: https://www.delfi.lv/kultura/news/art/kadusalutu-vajag-rigas-800-jubileja.d?id = 1033638

[12]Байе М. Р. Управленческая экономика и стратегия бизнеса (Managerial Economics and Business Strategy). - Москва, Юнити, 1999. с.

[13] Hardin G.J. The Tragedy of the Commons, -Science, 1968, pp. 1243-1247.

[14]Ван Хорн Дж. К., Вахович мл. Дж. М. Основы финансового менеджмента. Одиннадцатое издание. (Fundamentals of Financial Management. Eleventh Edition) - Москва, Издательский дом "Вильямс", 2003. 988 с.

[15]Fisher I. The Nature of Capital and Income. - New York: The Macmillan Company, 1906, 427 p. [online] [20.08.2011] Available at: http://books.google.lv.

[16] Боди 3., Мертон, Р.. Финансы: Перевод с англ. (Finance. Translation from English) - Москва, Издательский дом «Вильямс», 2004. 592 с.

[17] Jaunzems A., Bolezina I, Norkuss N. Neprivātu labumu ražošana un neprivātu ļaunumu novēršana Ventspils pilsētā un Talsu novadā. (Production of non-private goods and elimination of nonprivate bads in Ventspils city and Talsi disctrict) -Grāmata: "Sabiedrība un kultūra". Rakstu krājums, XVI, Liepāja: LiePA, 2014. pp. 518-532. 